\title{
Effectiveness of community forest association and water resource users' associations in discharging their statutory functions: A case of Kilungu catchment, Kenya
}

\author{
Patricia Mumbi Wambua*, Nzioka John Muthama, Thuita Thenya \\ Wangari Maathai Institute for Peace and Environmental Studies, University of Nairobi, Kenya \\ Article published on May 30, 2021
}

Key words: Community forest association (CFA), Water resource users associations (WRUA), Catchment management

\begin{abstract}
Catchment degradation has continued to occur globally albeit the presence of Community Forest Associations (CFA) and Water Resource Users Associations (WRUA). Similarly, Kilungu catchment area in Kenya is under the management of the Kenze (CFA) and upper Kaiti (WRUA). This paper examined Kenze CFA and Upper Kaiti WRUA activities by exploring their effectiveness in discharging their statutory functions. This was achieved by carrying out, an exploratory descriptive survey. Data was collected through questionnaires, focus group discussions, 10 key informants' interviews and direct observations. Descriptive analysis was used. Information was presented in fig.s, tables and percentages. Results showed that upper Kaiti WRUA as more effective in catchment management at moderately (31\%) and highly at (37\%) as compared to CFA moderately (29\%) and highly (5\%). In terms of discharging of their statutory functions, Upper Kaiti WRUA was better at a rating of $27 \%$ (good) and $23 \%$ (very good) as compared to Kenze CFA which was rated at $3 \%$ (good) and $6 \%$ (very good). This study results implied that Upper Kaiti WRUA was more effective in all aspects of ensuring catchment management as opposed to CFA. In conclusion, a strategy of seizing the opportunities presented by the CFA of being empowered to perform all its activities as required by law with emphasis on the timely preparation and implementation of management plans and WRUA's continuous improvement should be prioritized. The study recommends new initiatives that improve on the CFA and WRUA activities in order to effectively discharge on their statutory functions.
\end{abstract}

*Corresponding Author: Patricia Mumbi Wambua $₫$ patriciamukua@yahoo.com 


\section{Introduction}

Globally, majority of the continents of the world including America, Asia and Africa are promoting the implementation of community association activities by rural communities in the management and utilization of natural forest catchments through Participatory Forest Management (PFM). Many countries have already developed while others are in the process of developing, changes to national policies and legislation that institutionalize PFM in order to encourage catchment conservation and sustainable utilization of forest resources (Gordon and Ayiemba; Busck-Lumholt and Treue 2018).

In developing countries, the Community Forest Associations (CFAs) are adopted to manage threatened forests and ensure conservation of biodiversity through a process of inclusion, equity, and democratization (Amanor, 2003). For instance, during the 1990s, the activities of CFAs in Nepal were protection and management of forests with the clear aim of halting forest degradation focused on learning and exchange between user groups (Hobley and Shakya, 2012).

The Forest Act of 2005 saw the formation of the Kenya Forest Service (KFS), a semi-autonomous government agency with representation from various government ministries and under the same act Section 35 of the Forest Act 2005 made it mandatory for any forest (state, local authority or provisional forest, registered private forest) to be managed in accordance with an approved Forest Management Plan (FMP). The participatory forest management (PFM) approach further provides for local communities' engagement in the control and use of the forests to which they live adjacent to. Section 46 (4) and (5) of the Act require that applications by CFA to the Director KFS for permission to participate in conservation and management of forests be accompanied by draft management plans. Formation of the Community forest participation achieved primarily through CFAs, and integrated management of forests is the central principle motivating the new policy (GOK, 2005; 2007).
Studies reveal that the formation of CFAs started in 1997, mainly to encourage community participation in forest management. The CFAs are duly recognized and registered groups with the Attorney General 's office and comprise of forest adjacent communities living up to $5 \mathrm{~km}$ from the forest boundary, and who are recognized under the Forest Act as co-managers of the forests using Participatory Forest Management. To date a number of CFAs have been formed through sensitization of communities adjacent to the major forests in the country by the Kenya Forest Action Network (FAN) and the Kenya Forests Working Group (KFWG) as well as through the KFS (Thenya, et al., 2007). It is therefore possible for local communities to directly participate in protection, conservation, and management of a given forest area subject to provisions of a management plan for the forest (World Bank Report, 2007). In Kakamega forest for example, the Community Forest Association (CFA) known as the Kakamega Community Forest Association (KACOFA) formed in 2006 has been involved in various forest activities aimed at protecting the forest (Ongugo et al., 2008). Research shows that the activities of the CFAs as per the Kenya forest and conservation Act (2016) are majorly to actively prepare and implement participatory forest management plan (PFMP) in collaboration with KFS, enjoy user rights and provide any useful information to KFS for improvement of the management.

On the other hand, global research shows that traditionally collective communal water management have span for almost 1,000 years as witnessed in Spain. More than 100 years ago, the Spain 1879 Water Act facilitated the voluntary creation of irrigation communities (Del Saz, 1990). In 1985 through the same Water Act, new aspects appeared and Irrigation Communities were updated to include not just irrigation but other water users like public water supply and industries, thus becoming Water Resource User Associations (WRUAs). Further literature reveals that in Kenya the Water Resources Users Association was established by the Water Act (2002). In the act Water Resources Management Authority (WRMA) were expected to formulate 
Catchment Management Strategy for the management, use, development, conservation, protection and control of water resources within each catchment area (Water Act 2002 section 5, subsection 1). The catchment management strategy is to provide mechanism and facilities for enabling the public and communities to participate in managing the water resources within each catchment area and allows for conflict resolutions and co-operative management of water resources in catchment areas (Water Act 2002 section 5 , subsection $3[\mathrm{e}]$. (The WRUA formation and operation is as per section 10, sub sections 1 to 14 of the Water Resources Management rules 2007 and for the WRUAS activities to be objectively realized, there is an urgent need to espouse a holistic approach, (Cheptoo, 2006; Mitchell, 2005). In relation to the above background, Kenya adopted a basin-based approach to water resources management, which is a holistic methodology that provides for regulated use of the water resources for the benefit of communities.

The enactment of the water act (2002), as well as the Kenya constitution (2010) and the recent water act (2016) led to the concerted acknowledgement of the importance of community participation in the management of water resources, resulting in the formation of WRUAs within the six drainage areas of Kenya namely: Lake Victoria North basin, Lake Victoria south basin, Rift valley basin, Athi river basin, Tana river basin and the Ewaso N'giro river basin. According to the ministry of environment and natural resources the existence of Community Forest Associations (CFAs) and Water Resource Users Association (WRUAs) within different catchments distributed across the country ensures the effective management of the catchments (MENR 2007).

Makueni county falls within the Athi river basin catchment, it has nine (9) registered CFAs; namely: Makuli, Nzaui, Kamukima, Nthangu, Kitondo, Mbooni community forest association (MBOCOFOA), Kichapa, Makongo and Kenze respectively, and sixtyeight (68) registered WRUAs involved in various catchments management within the county. Due to erratic rainfalls the communities along the Kaiti River collaborated to form a WRUA in order to manage the river resources and hence Upper Kaiti WRUA formerly known as Kinzuma was formed in mid-2010. Upper Kaiti WRUA and Kenze Community Forest Associations (CFA) are the only institution currently in place managing the entire Kilungu catchment and its various tributaries of Kaiti river, Kikoko, Kisusyo, Isuuni river, Mitungu, Tiva, Mwanyani, Katulye, Kyau, Kaiti, Kilumwa, Kwanthi in Kilungu catchment (GOK, 2018). Kilungu catchment is of major economic and ecological importance in the area due to its value as a watershed and catchments area for the above rivers as well as it being a source of various springs namely Kikoko, Ilima, Kisusyo which is the source of Kisusyo river and tributaries and wet lands providing water to the community and supporting various livelihood activities. Literature reveals that the catchments population of more than 23,956 people made up of 4,372 households is spread out within the seven blocks of Kilungu, Kitumbuuni, Ndaatai, Kiongwani, Kenze, Nduluni and Kiio and its an epicenter of ecological support system for their livelihoods. Even with the presence of these institutions the catchment has experienced rampant degradation which is undermining the limited sustainable water and forest resources base in the country and these calls for vibrant CFA and WRUA activities in order to reverse the trend (Makueni CIDP, 2018-2022).

According to the county government of Makueni the activities of all the CFA and WRUA involved in the various catchment management activities and their contributions in the county is not known and the inadequacy of actionable data and information makes it increasingly difficult to make informed and transparent decisions on utilization of the catchment in a sustainable way (Makueni CIDP, 2018-2022). The aim of this study was generally to examine CFA and WRUA activities and their effectiveness in discharging their statutory functions in catchment management.

\section{Materials and methods}

Context, theory and conceptual framework

In order to examine Kenze CFA and Upper Kaiti

WRUA activities and their effectiveness in 
discharging their statutory functions, this study was based on the institutional theory focusing on the institutions activities, their effectiveness in discharging their statutory functions, their organizational structure and functioning, in catchment management and general environmental management (e.g. Bai and Sarkis, 2010,De Ron, 1998, Herron and Braiden, 2006, De Brito et al., 2008, Wong et al., 2012). The choice of institutional theory was premised on that it offers explanations as to why certain practices within institutions are chosen without an obvious economic return (Berrone et al., 2010; Meyer and Rowan, 1977, Dimaggio and Powell, 1983) and especially on why organizational structures and practices become entrenched and also on how and why change occurs Jennings (1994). The institutional theory guided the study by examining the process through which the Kenze CFA and Upper Kaiti WRUA institutional activities influenced the outcomes of the institutions contributions in Kilungu catchment management. The key outcomes of interest were the activities of Upper Kaiti WRUA and Kenze CFA especially on the aspects of performance on their activities, law enforcement, fines and penalties, effectiveness in delivery of desired outputs, officials leadership and their influences on the outcomes of the institutions contributions (Scott, 2004). The study further examined the coercive pressure especially on the KFS and WRA mandates in relation to CFA and WRUA specially to bring out the idea of how the CFA and WRUA institutions operate (Maggio \& Powell, 1991).

This was informed by the fact that the question of CFA and WRUA institutions activities is widely accepted as it emphasizes on the formal and legal aspects of the governance institutions. According to the institutional theory by Scott (2004) for institutions such as CFA and WRUA to be effective in catchment management the same should observe the sustainable rules and belief systems prevailing in the environment they operate in. Such evidence from existing studies activates an attempt to reach a deeper communication of the role played by CFA and WRUA activities and structure in discharging their statutory mandates in management of Kilungu catchment.

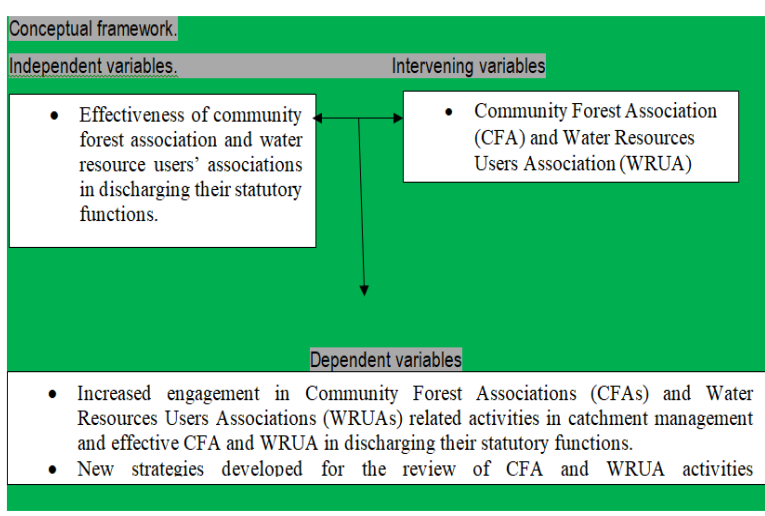

Fig. 1. Conceptual framework-researcher.

\section{Methodology}

The study area covers seven blocks whose residents directly or indirectly interact and depend on the catchment for their livelihoods (Fig. 2). The choice of Kilungu catchment as the study area was considered appropriate due to several reasons. First it had a registered Upper Kaiti Water Resources Association (WRUA) which was formed in the year 2011 and registered in the year 2013 and Kenze Community Forest Association (CFA) registered in the year 2013 involved in the management of the catchment and their activities, were not documented hence the need for the study. Second, the catchment portrays a classical example of a protected area where the CFA and WRUA activities and their contributions could be examined. Third, the area is surrounded by human communities spread out within the seven blocks of Kilungu, Kitumbuuni, Ndaatai, Kiongwani, Kenze, Nduluni and Kiio and it an epicenter of ecological support system for more than 23,956 people made up of 4,372 households who directly or indirectly interact on the catchment for their livelihoods (Makueni County Integrated Development Plan, 2018-2022).

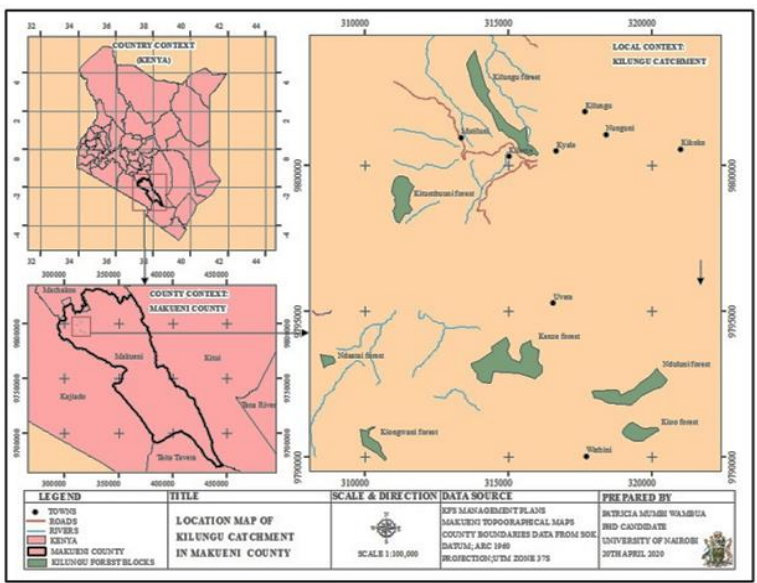

Fig. 2. Study area: Source MEMR-KFS 2020. 
The average annual rainfall, evaporation and temperatures are 600mm, 2000mm and $23^{\circ} \mathrm{c}$ respectively and rainfall is characterized by small total amounts, strong seasonal and bimodal distribution (Nyagito et al., 2008). The area is generally dry and faced with acute water shortage that has a direct impact on its economic development. This is attributed to periodic cyclical droughts and shrinking water sources due to encroachment and degradation of watersheds/ towers, uncontrolled sand harvesting and limited awareness on water harvesting and management among the populace. Combinations of cultural and socio-economic and human activities have also led to high rates of degradation and encroachment of the Kilungu catchment resources (Ontiri \& Robinson 2014). Two of the most important rivers traversing the Kilungu catchment include Kaiti and Kikuu Rivers; it's also the source of rivulets such as Mwanyani, Katulye, Kyau, Kaiti, Kilumwa, Kwanthi and Kilome Springs. They also serve as important recharge system for River Athi downstream. A descriptive survey was used to collect data from households who were residents of Kilungu, Kitumbuuni, Ndaatai, Kiongwani, Kenze, Nduluni and Kiio. Semi structured questionnaires, for each institution were administered to randomly selected 366 households who were obtained through Cochran's formula by Horse (2018) and Rucker (2017) as follows, based on a total household population of $4372=$ Cochran's sample size recommendation; = value (i.e. 1.96 for $95 \%$ confidence level); =proportion of the population with direct attribute to the sub catchment governance; = desired level of precision-confidence interval $\pm 7 \%=$ $( \pm 0.07)$ ) and population proportion $=50 \%$. The household questionnaires were shared equally to collect data on Community Forest Associations (CFAs) and Water Resource Users Associations (WRUAs) activities and their effectiveness in discharging their statutory functions.

Data was collected through 366 household questionnaires, 10 focus group discussions, 10 key informants' interviews and direct observations. Descriptive analysis was used. Information was presented in fig.s, tables and percentages.

\section{Results and discussions}

Respondents age in years

The age distribution of survey respondents is shown in fig. 3 below. Majority of the respondents for both the CFA and WRUA were between the ages of 30-39 where Kenze CFA had $45 \%$ and upper Kaiti WRUA had $33 \%$. This was followed by age range $40-49$ years where upper Kaiti WRUA had 32\% and Kenze CFA $17 \%$. In age bracket of 20-29 years, upper Kaiti had $17 \%$ and Kenze CFA 26\%. 50-59 year upper Kaiti WRUA had 16\% and Kenze CFA $11 \%$ and $\geq 60$ year upper Kaiti WRUA had $1 \%$ and Kenze CFA o\%. The results revealed that majority of the respondents in both the institutions were between the age bracket of 30-39.

This differed with earlier findings by Maskey et al. (2003) who observed that older people in Nepal tended to participate more in community forest and water associations programmes than younger people. However the results compared with a study done in Ondo State, Nigeria, which observed that most farmers within 35 to 54 years of age bracket participated more in the Taungya forestry system than other categories because they were able to plant trees and harvest them within their lifespan (Victor and Bakare, 2004).The results further agreed with previous studies done by Dolisca et al. (2006) who found that older people were mainly interested in collecting forest resources and managing water resources while young people were willing to contribute to the process of decision-making in forestry and water programmes.

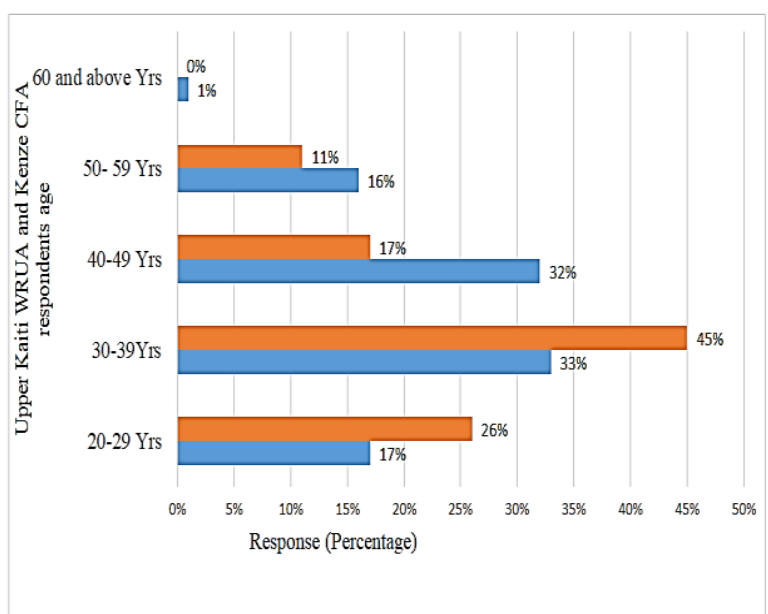

Fig. 3. Respondents age in years. 


\section{Education level of the respondents}

The study established that Kenze CFA respondents had higher level of education with secondary level (36\%), College (28\%) and University (3\%) as compared to upper Kaiti WRUAs (25\%) secondary level, college certificate (11\%) and none with a University degree as shown in fig. 4 below. This could mean that most people with higher levels of education are not in the rural areas but in urban centers or elsewhere seeking employment or even working there as a livelihood means and these has filtered the literacy levels within the study area. Further information generated from FGD and KII further suggested all issues which needed high literacy level of interrogation were attended and these was supported by the current study's observation that education did not determine community participation in catchment management and that other factors not levels of education were found to be contributing to the continuous catchment degradation.

These results agreed with previous studies done by Campos et al. (2012), Dolisca et al. (2007) and Sodhi et al. (2010a) who showed that formal education influenced perceptions on environmental, catchment conservation and ecosystem services provisioning.

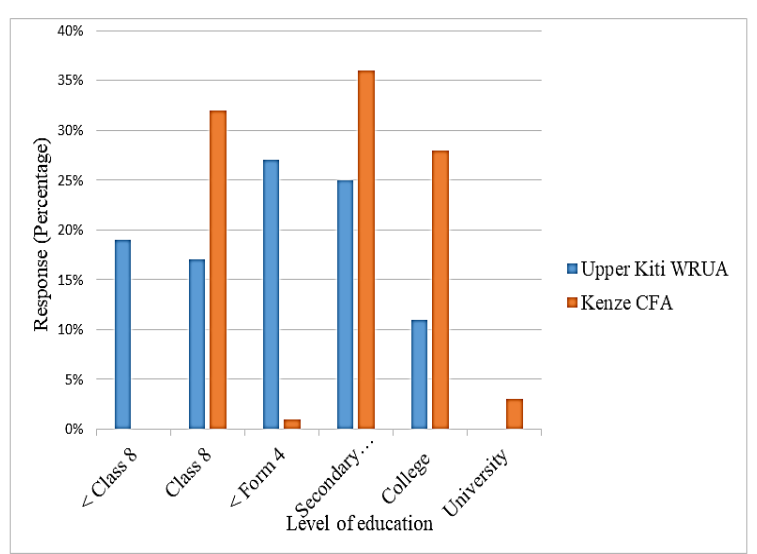

Fig. 4. Respondents level of education.

In addition, these results agreed with a study on community participation in social forestry in Zathila and Betaga villages in Gazipur, Bangladesh by Chowdhury (2004) who found out that people's level of education influenced their participation in forestry projects. A different study by Jakariya (2000) made similar observations that peoples' participation was influenced by educational level, in that the higher the literacy level the higher the level of catchment management.

Gender inclusivity and equity level of the respondents Analysis on whether WRUA and CFA organizations observed gender balance revealed that the WRUA structure accommodated gender balance better compared to the CFA in their activities. This was evidenced by $93 \%$ of WRUA responses being yes compared to $15 \%$ for CFA (Fig. 5). Further the FGD and KII confirmed that both genders in WRUA had equal opportunities of participating in all the WRUA activities. The respondents mentioned some of the activities they participated in without bias as attending all meetings, contributing in decisions and matters which affect them as equal members of the WRUA and being appointed in leadership positions. In addition, the respondents mentioned being appointed members of the subcommittee as well as chairperson are done without any biasness to either gender as opposed to CFAs. These results further imply a gender imbalance in the CFA involvement in CFA activities.

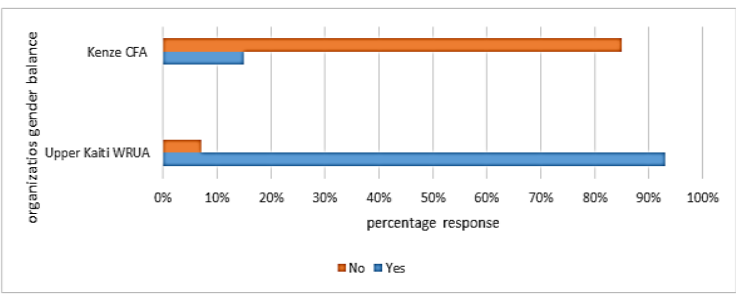

Fig. 5. Gender within the CFA and WRUA institutions.

Further the results revealed that WRUA as an organization was better in gender inclusivity and equity without a bias against the activities implementation by either gender. These was demonstrated by the results which showed WRUA at moderately (48\%), highly (29\%) as compared to CFA moderately (27\%), highly (14\%) meaning that gender discrimination and exclusion existed more in CFA activity implementation than in WRUA activity implementation, fig. 6 below. Based on the above findings, there should be an effort through policy to ensure a balance between the male and female involvement in catchment management. 


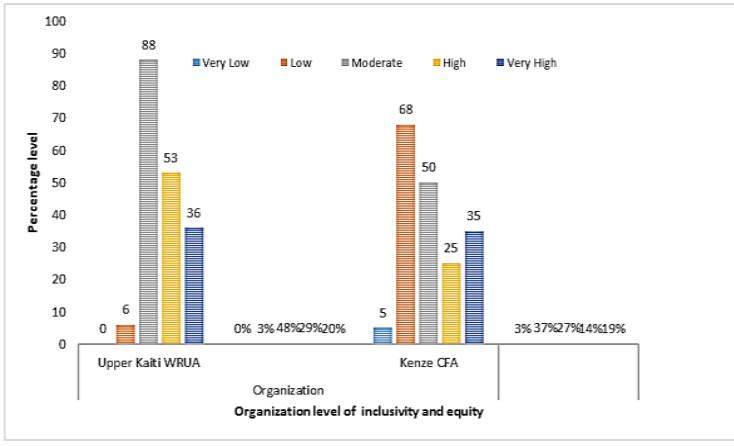

Fig. 6. Gender inclusivity and equity.

\section{WRUA and CFA implementation of activities}

The study showed upper Kaiti WRUAs activities as more effective in catchment management where $31 \%$ rated it as (moderately) and $37 \%$ rated it (highly) compared to CFA 29\% and 5\% for (moderately)and (highly) respectively (Fig. 7). Focus Group Discussions (FGD) and the Key Informant Interviews (KII) revealed that WRUA provides for exchange of information and ideas on the water resource use within the catchment. It also provides a platform for brain storming on potential projects and developments that may affect water usage with a view to obtaining the consent of other WRUA members and the public. In addition, WRUA was also involved in resolving conflicts arising from water use, lobbying for resources from various institutions including donors to improve availability, reliability, quality or other aspects of the water resources within Kilungu catchment. Further the discussions established that Mwanyani, Katulye, Kyau, Kaiti, Kilumwa, Kwanthi and Kilome springs as the main streams emanating from the Kilungu catchment. Discussion indicated that all the above springs have been mapped and Kaiti WRUA has been protecting Kilome and Kilumwa springs. On the other hand, the FGD and the KII revealed that the activities of CFA as required by law include to actively prepare and implement participatory forest management plan in collaboration with the KFS office, establishment of tree nurseries, planting of trees, conflict resolutions and general protection of the Kilungu catchment. Moreover, the discussions established that the CFA was expected to protect the catchment from illegal activities such as illegal logging, grazing inside the catchment, control of forest fires, sensitizing communities on conservation, enjoy user rights and provide any useful information to KFS for improvement of the catchment. However, results further indicated that the CFA activities were not delivering on these expectations and the catchment was said to be degraded. In addition, the FGD and the KII discussions revealed the reasons as to why the CFA were not effective in catchment management as due to inadequate funding, low levels of participation in CFA activities and unresolved conflicts among the members. Other factors were poor leadership and leadership wrangles and inadequate motivation among the members to do their work. Further, a lack of transparency and accountability at the top most level of Kenya Forest Service leadership were associated with problems such as illegal logging and corruption, marginalization and impoverishment of catchment dependent communities and the local people at large. The above results were further collaborated by the FGD which informed that weak forest and water resource governance as a major threat to the activities of the CFA and the WRUA. The threat was similarly blamed for unsustainable levels of catchment resource utilization leading to degradation.

These findings agreed with previous studies done by Davis et al. (2013) who established that the governance institutions execution of their functions leads to quality policies and sustainable resource use hence reduced degradation.

On the other hand, the reasons as to why the upper Kaiti WRUA was found to be more effective in catchment management were that the WRUA consistently held annual general meetings (AGM) without fail. Further, the FGD revealed that during AGM, new officials are elected after every three years with the next elections expected to take place in 2021. In addition, the WRUA had a work plan in place and an active executive committee in place to guide the affairs of the organization.

A key similarity between the Kenze CFA and upper Kaiti WRUA activities implementation was that both were formed to ensure an ecosystem based approach of managing the catchment. 
This is supposed to be achieved through an integrated management of land, water and other living resources within the study area. Based on the results, it was clear that in order to promote conservation and sustainable utilization of the catchment in an equitable way, the level of CFA and WRUA activities implementation needed to be reviewed to ensure their effectiveness. According to KII, there exists a structural arrangement conflict between the KFS and WRA in their coordination of the affairs of the CFA and WRUA respectively thereby affecting the implementation of their activities effectively.

The findings imply that the effective implementation of the activities of the CFA and WRUA are paramount for the conservation of the catchment. Further, there is an urgent need to improve on the activities of the CFA especially on participatory catchment management. This is in consistent with Watson (2007) who concluded that CFA activities should include community participation, cooperatively sharing, managing and conserving a common catchment resource. Further the involvement of the Community Forest Associations leads to improvements of forest conservation, rural livelihoods and forest governance (Lund \& Treue, 2008 and Tacconi, 2007). Moreover, several case studies have shown that decentralized catchment management results in effective control of catchment utilization (Lund \& Treue, 2008), enhances ecosystem functions and quality (Carter \& Gronow, 2005), enhances resource status (Sauer \& Abdallah, 2007) and sustainable management of forest resources by the local people (Ribot, 2004).

Further, these findings are consistent with those of Coulibaly-Lingani et al. (2011) who noted that a majority of those CFA implementing their activities as required by law in Burkina Faso were those receiving direct benefits from participating in such programs. Dolisca et al. (2006) similarly observed that respondents who had benefited from Forêt des Pins Reserve in Ahiti were more positively inclined towards social, environmental, and economic activities of catchments managements.

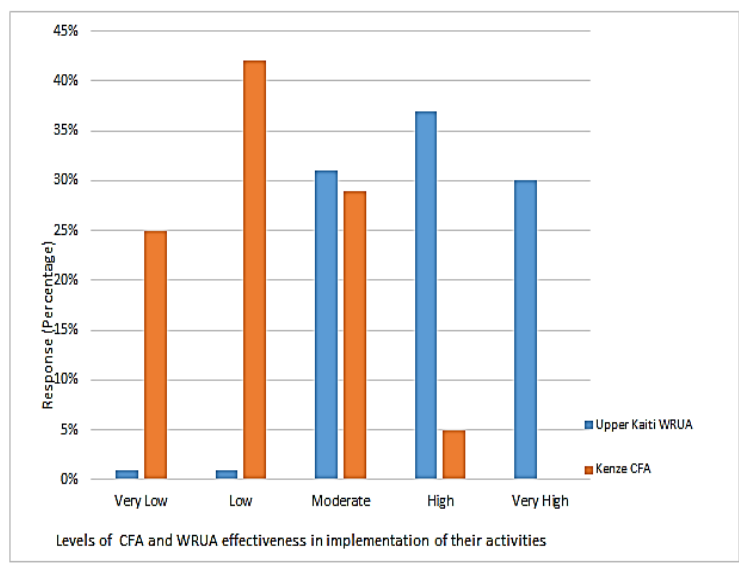

Fig. 7. WRUA and CFA implementation of activities.

WRUA and Kenze CFA discharging of their statutory functions and delivery of desired outputs in Kilungu Catchment

WRUA and Kenze CFA discharging of their statutory functions

In terms of discharging of their statutory functions, Upper Kaiti WRUA was found to be discharging its statutory functions better than the Kenze CFA. Out of all the WRUA respondents, 27\% chose level (good) and $23 \%$ (very good) as compared to Kenze CFA which was rated at only $3 \%$ (good) and 6\% (very good) as indicated in fig. 8 below.

The results were complimented by FGD and KII findings which had enumerated the statutory WRUA functions as involving the management of Kaiti river and other water resources within the catchment, preparation of sub catchment management plans (SCAMP), management of water resources within the catchment properly; and increase the availability of water resources. In addition, the discussions revealed that the WRUA as also involved in increase of the usage of the water for economic and social improvements; ensuring the upstream and downstream communities have access to water, protection of springs from degradation occasioned by animals and humans contamination. The WRUA was also involved in, advising on siting of boreholes, controlling sand harvesting from Kaiti river and its tributaries within the catchment, conflict resolution's, monitoring water use, monitoring activities carried out by members and training members in nursery management. 
Further WRUA was said to be involved in sensitizing the community against activities which may lead to degradation of the catchment including pollution of the springs in the catchment and community empowerment on matters of catchment management. On the other hand, Kenze CFA statutory functions were: Actively prepare and implement participatory forest management plan in collaboration with the KFS office, establishment of tree nurseries, planting of trees, conflict resolution's, control of forest fires and sensitizing communities on conservation. Other statutory activities were, protection of the forested hills, monitoring the forest condition, enjoy user rights and provide any useful information to KFS for improvement of the catchment.

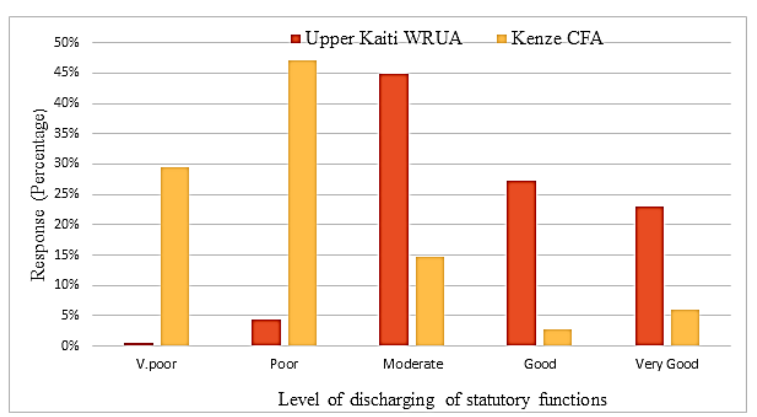

Fig. 8. Discharge of statutory functions by WRUA and CFA.

Upper Kaiti WRUA and Kenze CFA delivery of desired outputs in Kilungu Catchment

On the CFA and WRUA delivery of desired outputs in Kilungu catchment, the upper Kaiti WRUA was rated highly at moderate (40\%) and good (38\%) as compared to CFAs at moderate (26\%) good (4\%), fig. 9. The results were supported by both the focus group discussions and the key informant interviews which revealed that upper Kaiti WRUA was actively involved in the catchment management and had delivered desired output.in addition some of the key indicator of such delivery of desired aspects was there being the preparation of the Sub Catchment Management Plan (SCAMP), sensitizing the community against activities which may lead to degradation of the catchment including pollution of the springs in the catchment and community empowerment on matters of catchment management. Further the WRUA was found to be holding monthly meetings and engagements including the formation of Kaiti River Water Resource Users Associations Network (KWRUAN) a new entity to enhance the WRUA delivery of its functions. On the other hand, Kenze CFA had poor rating on its output delivery due to the fact that the CFA did not have a participatory forest management plan in place nor a work plan.

Further, the executive committee which was elected to oversee the management of the association was un accountable for ensuring the delivering of planned activities and the CFA executive leadership had not held an Annual General Meeting (AGM) for over a period of five years. Additionally, the officials of the CFA had overstayed without replacement for the same period and they did not have a resource mobiliser to source for funds from other partners such as the private sector, business community and even from the local and international civil societies. Lack of formal agreement between Kenze CFA and KFS including other development partners also affected the delivery of desired output.

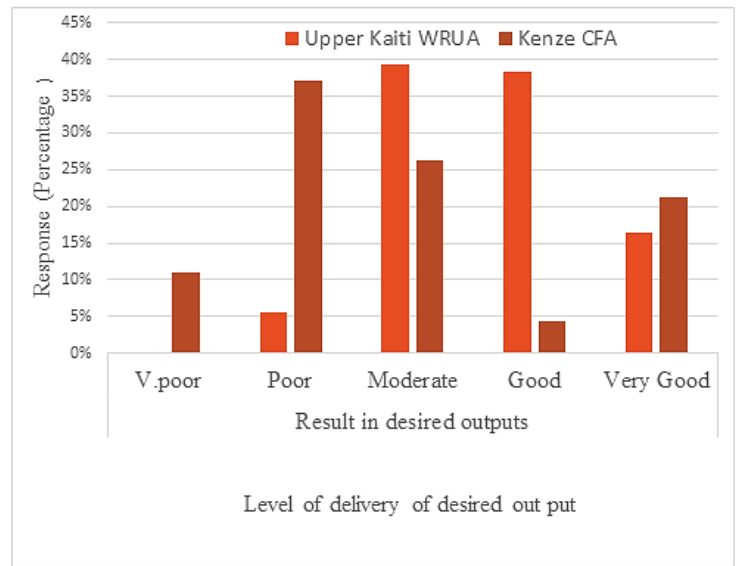

Fig. 9. Level of CFA and WRUA statutory functions expected delivery of desired outputs in catchment management.

Measures aimed at ensuring continuous delivery of desired outputs on catchment management Use of fines and penalties

On law enforcement and compliance, out of all the WRUA respondents, $41 \%$ (agreed) while $38 \%$ (moderately agreed) that, the use of more fines and penalties are important tools of enforcing compliance 
to laws aimed at ensuring catchment management as opposed to only $21 \%$ (moderately agree) and $20 \%$ (agree) for CFA as shown in fig. 10. These results imply that according to CFA respondents, fines and penalties serve little or no purpose in deterring noncompliance with the by-laws differing with previous studies done by Thenya (2007) who asserted that for the activities of CFA and by large the WRUA to be significant, then fines and penalties should be applied to defaulters of all the set rules and regulations.

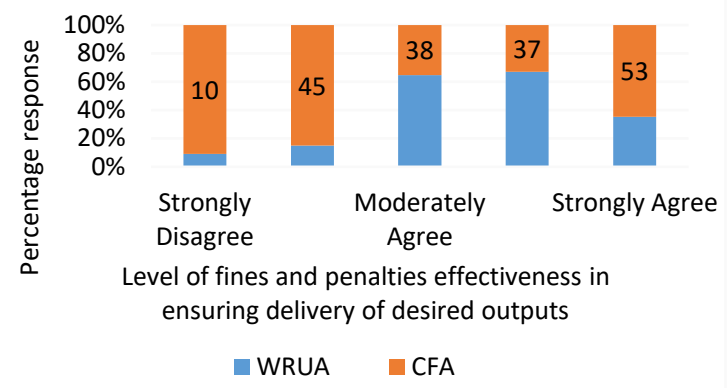

Fig. 10. more fines and penalties should be put in place to ensure compliance with the CFAs and WRUAs by laws.

Responsibilities of the WRUA and CFA institutional officials and community participation

Majority of the WRUA respondents, moderately agreed (43\%), agree (38\%) while CFA positively confirmed, moderately agree (32\%), agree (8\%) that in order for the Upper Kaiti WRUA and Kenze CFA to discharge their statutory functions and be effectiveness in delivery of desired outputs, then the WRUA and CFA institutional officials should attend to their roles and responsibilities effectively (fig. 11). These results were collaborated by the FGD and KII discussions which revealed that the key roles of the CFAs officials (Chairperson, Vice chair, Secretary and Treasurer) were resource mobilization, book keeping, participatory monitoring and evaluation including data collection and entry, leadership and governance, advocacy, conflict management and negotiation. On the other hand, the roles of WRUA officials (Chairperson, Vice chair, Secretary and Treasurer) included presiding over all meetings of the committee and at the general meetings. Vice Chairperson performs any duties of the Chairperson in his/her absence while the Secretary deals with all correspondences of the society among others.
The treasurer is responsible to the committee and to the member's proper books of account and ensures that all moneys received and paid by the society are recorded and available for inspection. Discussions further revealed that even though the officials existed in both the institutions, they didn't always comply with rules concerning elections as laid out in their governing documents. Some Executive Committees had not called for elections and the leadership had overstayed in office and majority of the officials absented themselves from meetings and failed on their roles and responsibilities, sometimes without apologies. The implication of these findings is that there is an urgent need of all the officials to attend to all their roles and responsibilities without fail in order for the institutions to deliver on their mandates.

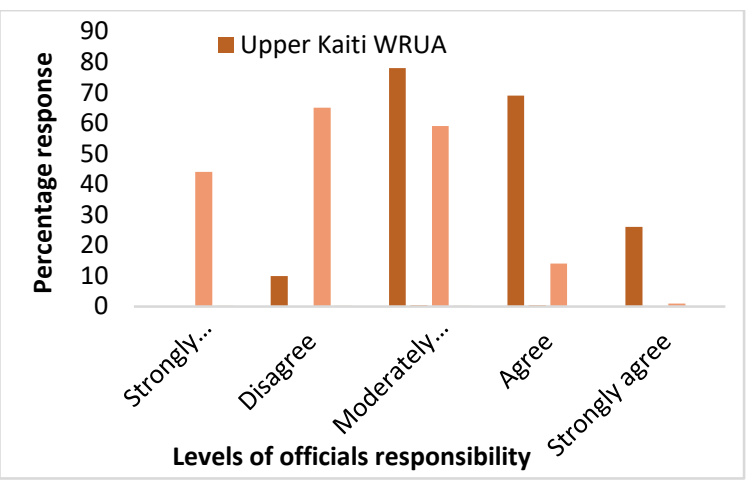

Fig. 11. Responsibilities of the WRUA and CFA officials.

\section{WRUA and CFA community participation}

According to the results, the WRUA respondents were more involved in community participation recording 26\% (moderately high) and 50\% (high agree) as compared to $23 \%$ (high) and 25\% (moderately high) for CFA as shown in fig. 12 below.

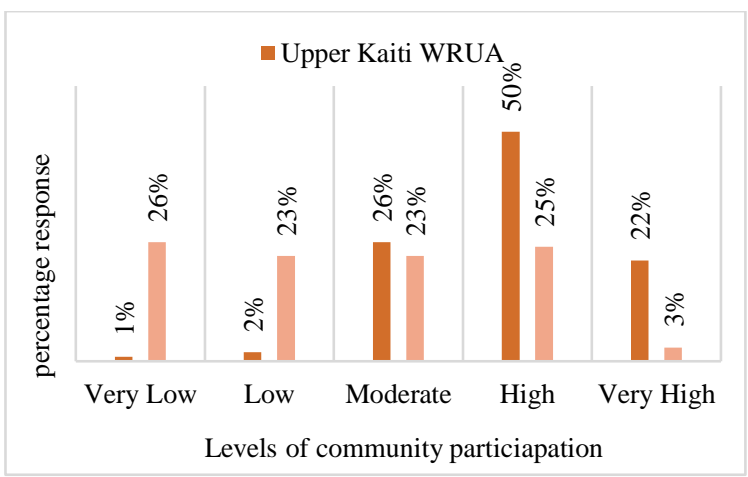

Fig. 12. Community participation in WRUA and CFA functions. 


\section{Conclusion}

In conclusion, the study achieved its objectives of examining the CFA and WRUA effectiveness in discharging their statutory functions in catchment management. Further Upper Kaiti WRUA was found to be more effective in all aspects: effective implementation of catchment management activities, discharging of its statutory functions, delivery of its desired outputs, application of fines and penalties, officials attending to their roles and community participation. This was in contrast with the CFA which was found to be insignificantly ineffective in all above aspects of catchment management. Importantly even though the study objective was achieved, it was further revealed that these did not fully address the catchment degradation, because the institutions, indicatively the CFA were not empowered to perform all its activities as required by law with emphasis on the timely preparation and implementation of management plans whereas the WRUA needed continuous improvement. In order to encourage community participation in all their institutional activities effectively there is an urgent need to review the level of CFA and WRUA activities implementation in a bid to improve on their effectiveness.

\section{Recommendations}

The study recommends development of a new strategy for the review of CFA and WRUA activities in order to ensure they effectively discharge on their statutory functions.

\section{Acknowledgement}

The authors are grateful to institutions and individuals who provided data and information towards this research. These include the Makueni county WRA office led by Stephen Ngao, WRUA chairman Antony Kimeu, Kaiti WRUA committee members, Makueni KFS office led by Mwanza and Veronica, foresters Kilungu catchment, CFA committee members, research assistants Daniel Ngoka and Muteti and Festus Mutiso for assistance in data analysis. We also thank our colleagues from WMI who provided insight and expertise that assisted the research.

\section{Compliance with ethical standards}

The research was carried out under Wangari Maathai Institute of Peace and Governance of the University of Nairobi. Consent of participants in interviews and questionnaire survey was sought before each individual participant. Permission was sought and granted by National Commission for Science, Technology and Innovation (NACOSTI).

\section{References}

Amanor KS. 2003. Natural and Cultural Assets and Participatory Forest Management in West Africa. Paper presented at the International Conference on Natural Assets. Philippines.

Bai and Sarkis 2010. Integrating sustainability into supplier selection with grey system and rough set methodologies Int. J. Prod. Econ 124(1), 252-264.

\section{Berrone P, Cruz C, Gómez-Mejia LR, Larraza}

M. 2010. Socioemotional wealth and organizational response to institutional pressures: do family controlled firms pollute less? Administrative Science Quarterly 55, 82-113.

\section{Carter J, Steenh B, Haldimann E, Akenshaev} N. 2003. Collaborative forest management in Kyrgyzstan: moving from top down to bottom up decision making. Gatekeeper Series 108. IIED

Cheptoo, Mitchell. 2005. Water resource users association policy and adaptive capacity.

\section{Coulibaly-Lingani P, Savadogo P, Tigabu M,} Oden PC. 2011. Factors influencing people's participation in the forest management program in Burkina Faso, West Africa. Forest Policy and Economics 13, 292-302

County Government of Makueni (CGM). 2013. County Integrated Development Plan (CIDP) Government Printers.

County Government of Makueni (CGM). 2018. County Integrated Development Plan 2018-2022 (CIDP). Government Printers. 
Davis, Lois M, Robert Bozick, Jennifer L Steele, Jessica Saunders, Jeremy NV. 2014. Miles, Evaluating the Effectiveness of Correctional Education: A Meta-Analysis of Programs That Provide Education to Incarcerated Adults, Santa Monica, Calif.: RAND Corporation, RR-266-BJA, 2013. As of February 3, http://www.rand.org /pubs/research_reports/RR266.html

De Brito, Brito MPde, Carbone V, Blanquart CM. 2008. Towards a sustainable fashion retail supply chain in Europe: organization and performance Int. J. Prod. Econ 114 (2), 534-553.

De Ron, Ron AJde. 1998. Sustainable production: the ultimate result of a continuous improvement Int. J. Prod. Econ 56-57 (1), 99-110

Del Saz, 1990. Water policy in Spain.

DiMaggio PJ. 1988. Interest and agency in institutional theory. In: Zucker, L. (Ed.).

DiMaggio PJ. 1988. Interest and agency in institutional theory. In: Zucker, L. (Ed.), Institutional Patterns and Organizations: Culture and Environment. Ballinger Publishing Company, Cambridge, MA pp. 3-22.

DiMaggio PJ, Powell WW (Eds.). 1991. The New Institutionalism in Organizational Analysis. University of Chicago Press, Chicago, IL.

DiMaggio PJ, Powell WW (Eds.). 1991. The New Institutionalism in Organizational Analysis. University of Chicago Press, Chicago, IL.

DiMaggio PJ, Powell WW. 1983. The iron cage revisited: Institutional isomorphism and collective rationality in organizational fields. American Sociological review 48 (2), 147-

DiMaggio PJ, Powell WW. 1983. The iron cage revisited: Institutional isomorphism and collective rationality in organizational fields. American Sociological Review 48(2), 147-160.
Dolisca F, Carter DR, McDaniel JM, Shannon DA, Jolly CM. 2006. Factors influencing farmer's participation in forestry management programs. A case study from Haiti. Forest Ecology and Management 236, 324-331.

Forest Policy and Economics, Sodhi NS, Posa MRC, Lee TM, Bickford D, Koh LP, Brook BW. 2010. The state and conservation of Southeast Asian biodiversity. Biodivers Conservation 9(5), 421-43.

GoK. 2009. Rehabilitation of the Mau Forest Ecosystem; Project Concept by the Interim Coordinating Secretariat, Office of the Prime Minister, September 2009

Government of the Republic of Kenya. 2007. Water Resource Management Rules, Laws of Kenya. Government Printer Republic of Kenya.

\section{Government of the Republic of Kenya. 2005.}

Herron and Braiden, Herron C, Braiden PM. 2006. A methodology for developing sustainable quantifiable productivity improvement in manufacturing companies Int. J. Prod. Econ 104 (1), 143-153

Horse Theme. 2018. Statistics How To Theme http://www.statisticshowto.com/probability-andstatistics/find-sample-size/ Accessed on 12.1.2018 Kenya forest Act. 2005

Kenya forest and conservation Act. 2016

Kenya Water Act. 2002 and 2016

Lund JF, Treue T. 2008. Are we getting there? Evidence of decentralized forest management from the Tanzanian miombo woodlands. World Development 36, 2780-280o.

Lund JF, Balooni K, Casse T. 2009. Change we can believe in? Reviewing studies on the conservation impact of popular participation in forest management. Conservation and Society 7(2), 71-82.

Lund JF, Helles F, Treue T. 2007. Decentralised forest management: reasons for official ambiguities and guide to donors [www document]. URL http://en.sl.life.ku.dk/upload/ policy_briefs__1.pdf 
Management Conference, KEFRI Headquarters, Nairobi, Kenya. 2007.

Maskey V, Gebremedhin TG, Dalton TJ. 2003.

A Survey Analysis of Participation in a Community Forest Management in Nepal. Res. Paper 8.

Maskey V, Gebremedhin TG, Dalton TJ. 2003. A Survey Analysis of Participation in a Community Forest Management in Nepal. Res. Paper 8.

MEMR. 2007. Masterplan for the Conservation and Sustainable Management of Water Catchment Areas in Kenya”. Nairobi: Government printers Retrieved from https://www.preventionweb.net/files/ 34692

Meyer and Rowan, Meyer J , Rowan B. 1977. Institutionalized organizations: formal structure as myth and ceremony Am. J. Sociol 83(2), 340-363

\section{Moss C, Schreckenberg K, Luttrell C, Thassim}

E. 2005. Participatory Forest Management and Poverty Reduction.

Noordin Q, Bashir J. 2000. Management of Catchment Areas in Sustainable Environment of Lake Waters and Poverty Alleviation: Cited in: Sustainable Environmental Management for Poverty Alleviation in the Lake Victoria Basin; Workshop Proceedings.

Nyangito MM, Musimba NKR, Nyariki DM. 2008. Range use and dynamics in the agropastoral system of southeastern Kenya. African Journal of Environmental Science and Technology 2(8), 220-230.

Ongugo P, Mbuvi M, Koech C, Maua J. 2007. Challenges to Improving Governance in PFM. In: Participatory Forest Management (PFM), Biodiversity, and Livelihoods in Africa. Proceedings of an international conference. 19-21 March 2007. Addis Ababa, Ethiopia. Pp. 145-150
Ongugo PO, Obonyo E, Mogoi JN, Oeba VO. 2008. The Effect of Internal Human Conflicts on Forest Conservation and Sustainable Development in Kenya. Paper presented in the IASC Conference, England. 2008

Ontiri E, Robinson LW. 2015. North lowland Ewaso Ngiro rangelands: Initial system analysis. Report to the LGACC project.

Ontiri E, Robinson LW. 2016. North lowland Ewaso Ngiro rangelands: Governance assessment. Report to the LGACC project Robinson LW, Ontiri E, Alemu T, Moiko SS. 2017. Transcending landscapes: Working across scales and levels in pastoralist rangeland governance.

Paul J DiMaggio, Walter W Powell. 1999. The Iron Cage Revisited: Institutional Isomorphism and Collective Rationality in Water Resources Management Rules 2007.

Ribot JC. 2002. Democratic Decentralization of Natural Resources: Institutionalizing Popular Participation. Washington, DC: World Resources Institute.

Ribot JC. 2004. Democratic decentralization of natural resources: Institutional choice and discretionary power transfers in sub-saharan Africa. Public Administr. Dev 23, 53-65.

Rucker Mike. 2017. How to determine the sample size for your study Category.

Sauer J, Abdallah JM. 2007. Forest diversity, tobacco production and resource management in Tanzani a.

Scott WR. 2008. Approaching adulthood: The maturing of institutional theory. Theory and Society 37, 427-442.

Thenya T. 2017. High community expectation against low societal transformation through community based income generating activities. Analysis of Participatory forest management in Kenya 2005-2013. 
Thenya T, Wandago B, Nahama ET. 2007. "Participatory forest management experience in Kenya (1996-2006)," in Proceedings of the $1^{\text {st }}$ National Participatory Forest.
Wong CWY, Shang Leung CSLuTKP. 2012. Green operations and the moderating role of environmental management capability of suppliers on manufacturing firm performance Int. J. Prod. Econ 140, 283-294.

World Bank Report. 2007. 